\title{
PENGELOLAAN LIMBAH BATIK CAIR SECARA BIOLOGIS PADA UKM BATIK MUTIARA HASTA DAN KATUN UNGU SEMARANG
}

\author{
Budi Warsito ${ }^{1}$, Endang Purbowati ${ }^{2}$ dan Sri Sumiyati ${ }^{3}$ \\ ${ }^{1}$ Departemen Statistika Fakultas Sains dan Matematika Universitas Diponegoro \\ ${ }^{2}$ Departemen Peternakan Fakultas Pertanian dan Peternakan Universitas Diponegoro \\ ${ }^{3}$ Departemen Teknik Lingkungan Fakultas Teknik Universitas Diponegoro \\ Email: budiwrst2@gmail.com
}

\begin{abstract}
ABSTRAK
Batik merupakan salah satu peninggalan budaya nenek moyang bangsa Indonesia yang perlu terus dipelihara dan dilestarikan. Salah satu persoalan yang muncul dari usaha pembuatan batik adalah limbah yang dihasilkan. Limbah yang langsung dibuang tanpa proses penyaringan terlebih dahulu sehingga dapat membahayakan bagi lingkungan. Oleh karena itu perlu dilakukan kegiatan pendampingan bagi para pengusaha batik agar melakukan pengolahan lebih dahulu limbah yang dihasilkan sebelum dibuang ke lingkungan. Kegiatan pengabdian masyarakat ini dilakukan melalui tahapan penyuluhan bagi UKM batik Mutiara Hasta dan Katun Ungu di Kota Semarang serta pembuatan bak pengolah limbah secara biologis dengan media meliputi kerikil, kerakal, bioball dan batu zeolit. Kadar polutan pada limbah yang dihasilkan dari kedua UKM tersebut jauh melebihi ambang batas yang diijinkan. Melalui pengolahan limbah secara biologis diharapkan limbah yang dibuang tidak lagi membahayakan lingkungan dan UKM dapat melakukan pengolahan secara berkelanjutan karena metode ini tidak memerlukan biaya yang besar.
\end{abstract}

Kata Kunci: limbah batik, Mutiara Hasta, Katun Ungu, zeolit

\section{PENDAHULUAN}

Batik merupakan kain bergambar yang pembuatannya secara khusus dengan menuliskan atau menerakan malam pada kain itu, kemudian pengolahannya diproses dengan cara tertentu yang memiliki kekhasan. Batik merupakan salah satu peninggalan budaya nenek moyang bangsa Indonesia yang perlu terus dipelihara dan dilestarikan. Batik Indonesia, sebagai keseluruhan teknik, teknologi, serta pengembangan motif dan budaya yang terkait, oleh UNESCO telah ditetapkan sebagai Warisan Kemanusiaan untuk Budaya Lisan dan Nonbendawi (Masterpieces of the Oral and Intangible Heritage of Humanity) sejak 2 Oktober 2009. Salah satu persoalan yang muncul dari usaha pembuatan batik adalah limbah yang dihasilkan. Secara realita limbah batik menjadi persoalan yang masih sulit untuk ditanggulangi, karena setiap produsen setiap hari membuang air limbah yang tercampur obat batik. Limbah itu banyak yang dialirkan ke sungai tanpa proses penyaringan terlebih dahulu sehingga dapat membahayakan bagi lingkungan. Limbah zat warna yang dihasilkan dari industri batik umumnya merupakan senyawa organik non-biodegradable yang dapat menyebabkan pencemaran lingkungan terutama perairan (Lestari dan Agung, ). Upaya yang dilakukan untuk mengatasi dampak negatif pencemaran limbah cair industri batik adalah dengan melakukan pengolahan terlebih dahulu (Tangahu dan Ningsih, 2016). Oleh karena itu perlu dilakukan penyuluhan bagi para pengusaha batik agar dapat mengolah lebih dahulu limbah yang dihasilkan sebelum dibuang ke lingkungan.

Usaha Kecil Menengah (UKM) batik yang menjadi sasaran program adalah UKM 
Mutiara Hasta dan UKM Katun Ungu. UKM Mutiara Hasta lebih menitikberatkan pada penyelenggara kursus dan pelatihan batik klasik dan kontemporer, disamping juga menghasilkan produk sendiri (Slamet, 2016). Sedangkan UKM Katun Ungu merupakan sebuah paguyuban yang beranggotakan para tuna rungu di kota Semarang. Paguyuban ini didirikan pada tanggal 20 Oktober 2013 dan merupakan satu-satunya UKM Tuna Rungu pengrajin batik di Indonesia. UKM ini khusus memproduksi batik klasik dan kontemporer.

Secara legalitas UKM Mutiara Hasta bernama lengkap Batik Courses Classical \& Contemporary (MHBCC \& C) secara resmi berdiri pada tanggal 15 Oktober 1990 merupakan lembaga yang secara khusus menyelenggarakan kursus pelatihan membatik klasik dan kontemporer dengan spesifikasi pada batik kontemporer serta pewarnaan alami dan sintetis, disamping juga menghasilkan produk batik. UKM ini mendapat rekomendasi penyelenggaraan pelatihan dalam bidang Batik dari Dinas Perindustrian dan Perdagangan Provinsi Jawa Tengah.

Pola hubungan kerja antara UKM Mutiara Hasta dan UKM Katun Ungu adalah keduanya sebagai UKM yang saling mendukung. UKM Katun Ungu didirikan atas inisiatif dan kesepakatan peserta pelatihan membatik di bawah sanggar Mutiara Hasta. UKM yang beranggotakan para tuna rungu ini baru mempunyai kemampuan sebatas produksi saja, sedangkan UKM Mutiara Hasta yang lebih maju selain menghasilkan produk, menyelenggarakan pelatihan juga memasarkan produk jadi. UKM Katun Ungu juga menjadi pemasok bagi kebutuhan produk siap jual bagi UKM Mutiara Hasta. Jadi diantara kedua UKM saling terjalin komunikasi positif untuk menghasilkan karya yang berkualitas dan pemasaran yang efektif. Kedua UKM sama-sama mensukseskan pemberdayaan masyarakat dan mensejahterakan masyarakat melalui kerajinan batik. Melalui program pengabdian kepada masyarakat diharapkan terjalin kemitraan sinergis antara UNDIP sebagai pendamping kegiatan, UKM sebagai pelaksana kegiatan pemberdayaan masyarakat dan stakeholder terkait seperti Dinas Perindustrian dan Perdagangan, Dinas Tenaga Kerja dan Transmigrasi serta Pemerintah Kota Semarang sebagai pemangku kepentingan.

Kegiatan pengelolaan limbah batik ini merupakan bagian dari program pengabdian kepada masyarakat Ipteks bagi Program Unggulan Daerah (IbPUD). Program IbPUD ini penting sebagai solusi permasalahan dan pengembangan kedua UKM Mitra. Bagi UKM Mutiara Hasta program ini diharapkan dapat meningkatkan profesionalitas dalam menyelenggarakan pelatihan meliputi aspek promosi, kelayakan tempat pelatihan, administrasi, kualitas SDM dan pelaksanaan kegiatan pelatihan. Sedangkan bagi UKM Katun Ungu program ini diharapkan dapat meningkatkan kualitas produksi meliputi ketersediaan SOP produk dan keselamatan kerja, terjaminnya kesehatan kerja, diversifikasi produk, manajemen usaha, serta pengelolaan limbah yang ramah lingkungan. Berdasarkan analisis situasi dapat diidentifikasi permasalahan dari kedua UKM tersebut untuk mencari solusi guna meningkatkan profesionalitas usaha.

Kegiatan pelatihan pengelolaan limbah batik ini bertujuan untuk mensosialisasikan pengelolaan limbah secara umum serta limbah batik secara khusus yang aman bagi lingkungan serta praktek pembuatan alat pengolah limbah melalui media biofilter dengan pengolahan secara biologis. Melalui kegiatan ini diharapkan timbul kesadaran bagi kedua UKM batik untuk mengolah limbah yang dihasilkan dari proses produksi sehingga tidak membahayakan lingkungan. Pembuatan bak pengolah limbah juga dilakukan sebagai bantuan dari program IbPUD.

\section{METODE pelaksanaan}

Kegiatan pengabdian kepada masyarakat ini dilaksanakan dengan metode penyuluhan proses pengolahan limbah secara biologis 
serta dilanjutkan dengan pembuatan bak penampung limbah. Penyuluhan dilakukan melalui penjelasan urgensi pengolahan limbah dan efek samping yang ditimbulkan apabila limbah langsung dibuang ke lingkungan. Penyuluhan dilakukan terhadap pemilik UKM batik Mutiara Hasta serta pengurus UKM batik Katun Ungu. Selanjutnya dijelaskan pula berbagai macam proses pengolahan limbah baik secara fisika, kimia maupun secara biologis. Menurut Riyanto dkk (2017), pengolahan limbah secara kimia tidak ramah terhadap lingkungan sedangkan pengolahan secara fisika cenderung memerlukan biaya tinggi. Dengan mempertimbangkan sustainability atau keberlanjutan dari program maka dipilih pengolahan limbah secara biologis. Memang proses yang terjadi melalui pengolahan secara biologis ini lebih lama dan hasilnya tidak bisa maksimal namun kelebihannya adalah disamping lebih murah, bahan baku yang dijadikan media juga lebih murah. Dengan demikian diharapkan nantinya setelah program pengabdian telah selesai dilaksanakan pengolahan limbah tetap dilakukan karena tidak terlalu memberatkan bagi UKM. Media yang digunakan dalam proses pengolahan limbah batik ini meliputi zeolit, bioball, kerakal dan kerikil. Tahapan pengabdian selanjutnya adalah melakukan pembuatan bak pengolah limbah sesuai dengan teori yang diberikan. Ilustrasi desain bak pengolah limbah disajikan pada Gambar 1.

Desain yang dibuat disesuaikan dengan lokasi pembuangan limbah. Ukuran bak yang digunakan juga disesuaikan dengan luas area yang dimiliki serta volume limbah yang dihasilkan. Derajat kemiringan dari pemasangan bak pada lobang tanah juga diatur karena akan mempengaruhi kecepatan aliran air limbah antar bak dan saluran pembuangan.

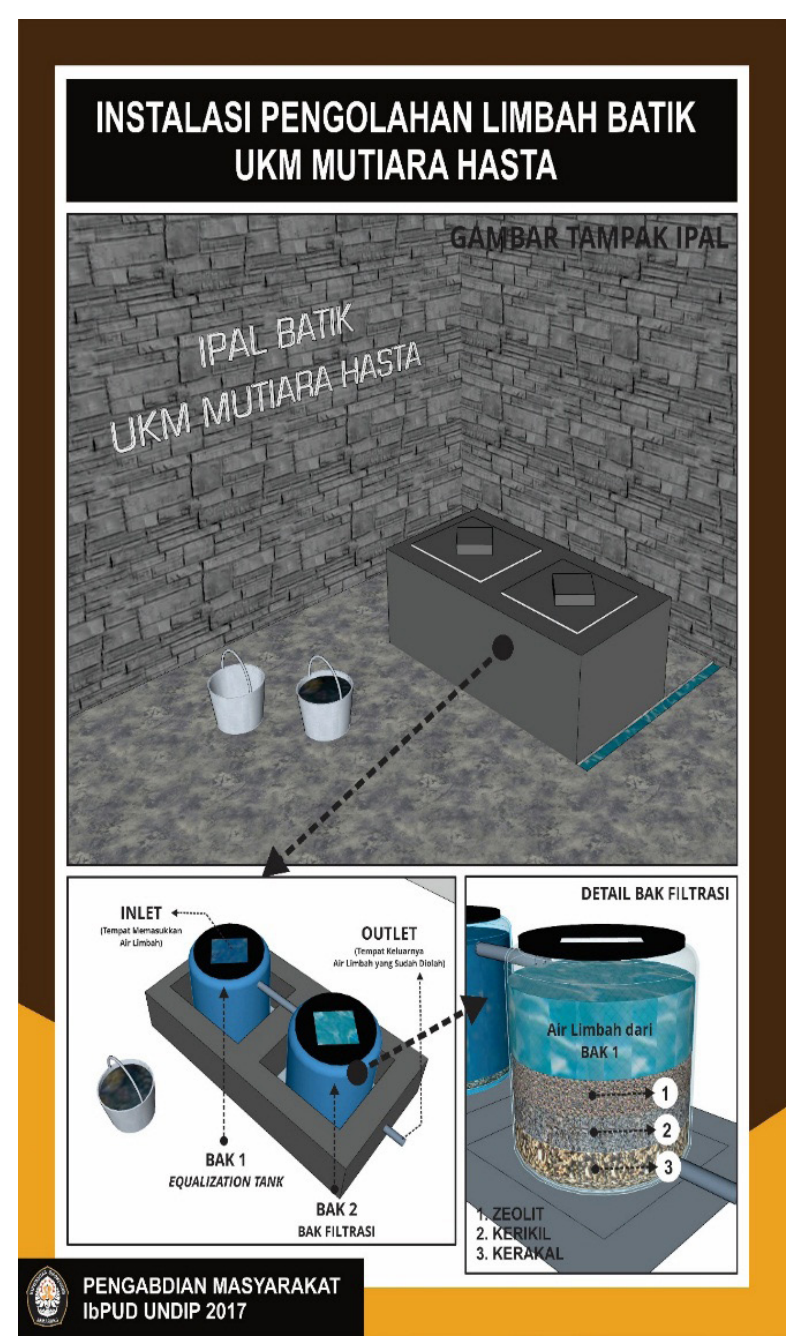

Gambar 1. Ilustrasi bak pengolah limbah batik

\section{HASIL DAN LUARAN}

Bagian Pelaksanaan kegiatan pengabdian kepada masyarakat ini dilakukan sesuai dengan metode yang diusulkan yaitu melalui dua tahapan meliputi penyuluhan pada pemilik dan pengurus UKM Batik Mutiara Hasta dan Katun Ungu serta praktek pembuatan bak pengolah limbah. Penyuluhan dilakukan melalui penjelasan tentang bahaya yang ditimbulkan dari limbah kimia batik apabila langsung dibuang ke lingkungan, baik penjelasan secara teoritis maupun teknis realita. Kemudian dijelaskan beberapa jenis cara pengolahan limbah baik secara fisika, kimia maupun biologis serta manfaat yang bisa diperoleh dengan melakukan pengolahan terhadap limbah sebelum dibuang ke lingkungan. Tabel 1 menyajikan data beberapa zat pencemar yang terkandung dalam limbah 
batik dari UKM Mutiara Hasta dan Katun Ungu. Pengujian dilakukan terhadap limbah batik yang langsung diambil di lokasi UKM dan telah diuji di Laboratorium Lingkungan Departemen Teknik Lingkungan Fakultas Teknik Universitas Diponegoro.

Tabel 1. Kandungan beberapa zat pencemar dalam limbah batik dari UKM mitra

\begin{tabular}{llccc}
\hline No Parameter & Satuan & $\begin{array}{c}\text { Air } \\
\text { limbah }\end{array}$ & $\begin{array}{c}\text { Kadar } \\
\text { Maksimum }\end{array}$ \\
\hline 1 & BOD & $\mathrm{mg} / 1$ & $8.244,00$ & 30 \\
2 & TSS & $\mathrm{mg} / 1$ & $2.564,00$ & 30 \\
3 & Minyak & $\mathrm{mg} / 1$ & 16,00 & 5 \\
& Lemak & & & \\
4 & COD & $\mathrm{mg} / 1$ & $23.554,00$ & 100 \\
5 & Amonia & $\mathrm{mg} / 1$ & 66,33 & 10 \\
6 & $\mathrm{pH}$ & - & 6,61 & $6-9$ \\
7 & $\mathrm{Cr}$ & $\mathrm{mg} / 1$ & 0,22 & - \\
\hline
\end{tabular}

Sumber : data primer hasil pengolahan limbah batik UKM Mutiara Hasta (2017)

Dari hasil pengukuran terhadap kadar polutan dari limbah pabrik kedua UKM mitra sebagaimana terlihat pada Tabel 1 nampak bahwa hampir semua kandungan jauh melebihi ambang batas yang dipersyaratkan sebagaimana pada Peraturan Menteri KLH No 5 tahun 2014. Oleh karena itu diperlukan pengolahan terlebih dahulu sebelum limbah tersebut dibuang ke lingkungan.

Tahapan berikutnya dari kegiatan ini adalah pembuatan bak pengolah limbah pada lokasi pembuangan limbah batik di UKM Mutiara Hasta. Pada bagian ini dilakukan pembuatan bak pengolah limbah dengan metode biologis. Lubang pertama adalah tempat penampungan limbah batik yang nantinya diisi dengan limbah cair sisa membatik. Dari bak penampungan limbah ini air limbah dialirkan ke bak penampungan yang kedua. Bak ini berfungsi sebagai tempat pengendapan limbah sehingga kandungan zat berbahaya dapat berkurang. Ukuran bak disesuaikan dengan lokasi yang tersedia dan banyaknya limbah yang dihasilkan. Untuk memudahkan pengerjaan dan menjaga agar air limbah tidak mudah meresap secara langsung ke dalam tanah maka pada bak pengendapan ini air limbah ditampung dalam bak tampung berupa tandon besar yang terbuat dari plastik. Setelah air limbah diendapkan selanjutnya dialirkan ke bak penampungan yang ketiga yang juga berupa tandon besar. Kedua tandon ditaruh di dalam lubang tanah ukurannya disesuaikan dengan ukuran tandon dengan kedalaman yang memadai sedemikian hingga air limbah dapat mengalir dengan mudah dari tandon pertama ke tandon kedua. Antar tandon penampung limbah dihubungkan dengan pipa pralon berukuran 3 inci. Pada tandon kedua ini diisi dengan media yang berfungsi dalam pengolahan air limbah secara biologis yang terdiri dari beberapa lapisan media. Lapisan paling bawah adalah batu kerikil dengan ketinggian sekitar $5 \mathrm{~cm}$. Lapisan kedua berupa kerakal dengan kedalaman yang hampir sama. Lapisan berikutnya adalah bioball yang berfungsi sebagai tempat tumbuhnya mikroorganisme. Lapisan paling atas adalah batu zeolit dengan ketinggian sekitar $10 \mathrm{~cm}$. Beberapa gambar berikut menyajikan kegiatan proses pembuatan bak pengolah limbah batik di UKM mitra. Tahapan kegiatan meliputi persiapan tandon hingga pembuatan bak tempat menaruh tandon serta pembuatan saluran yang menghubungkan bak penampung terakhir ke tempat pembuangan limbah akhir. 


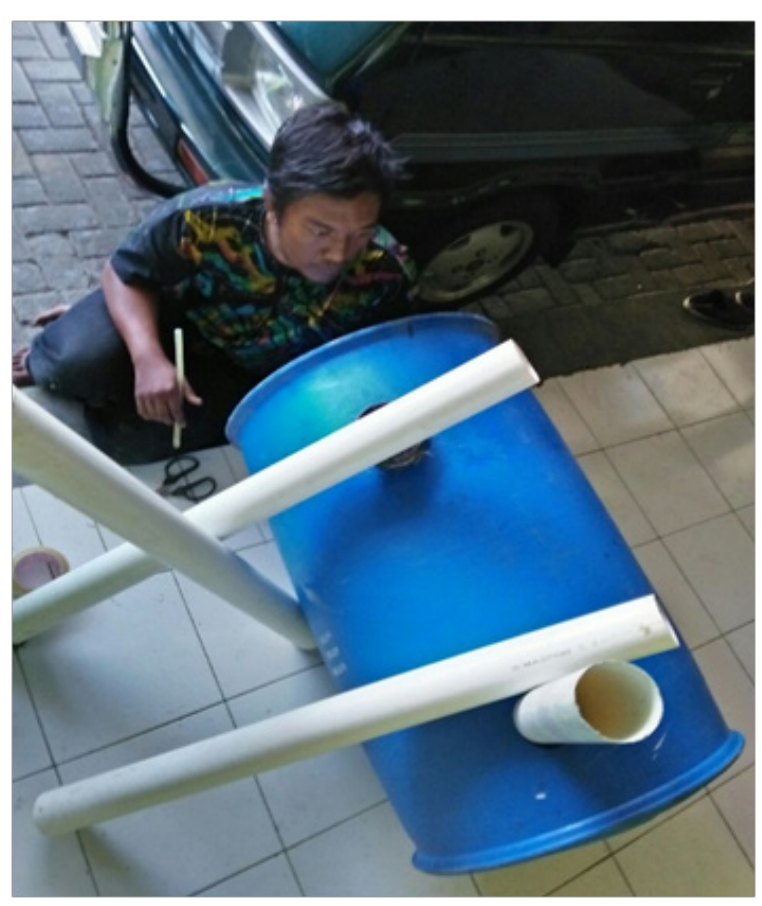

Gambar 2. Persiapan penyambungan tandon dengan pipa penghubung

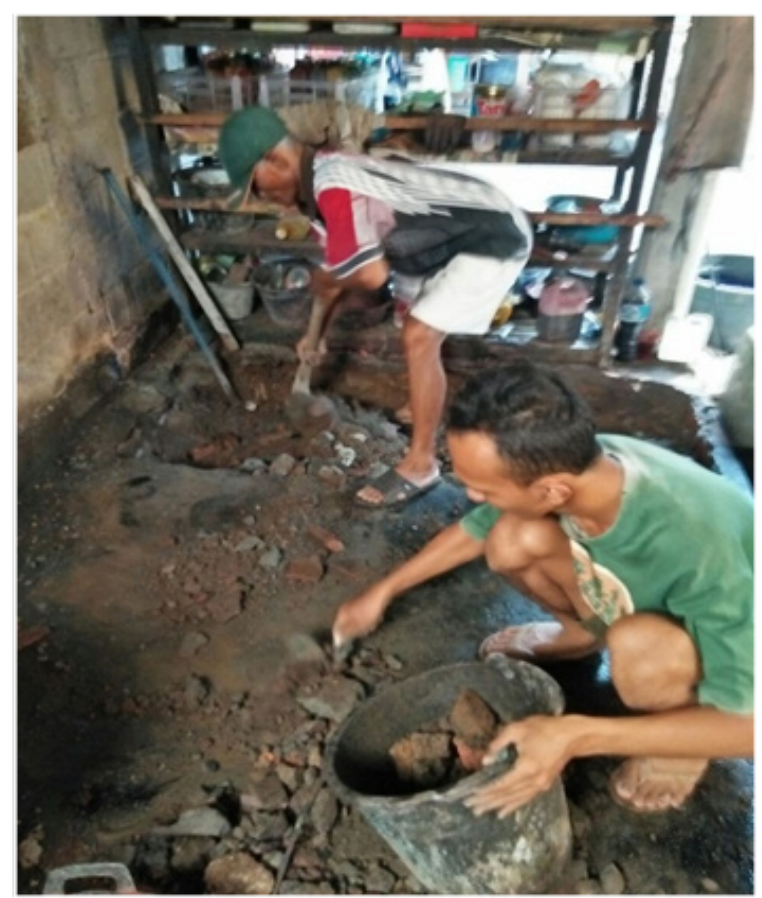

Gambar 3. Persiapan lokasi bak tampungan

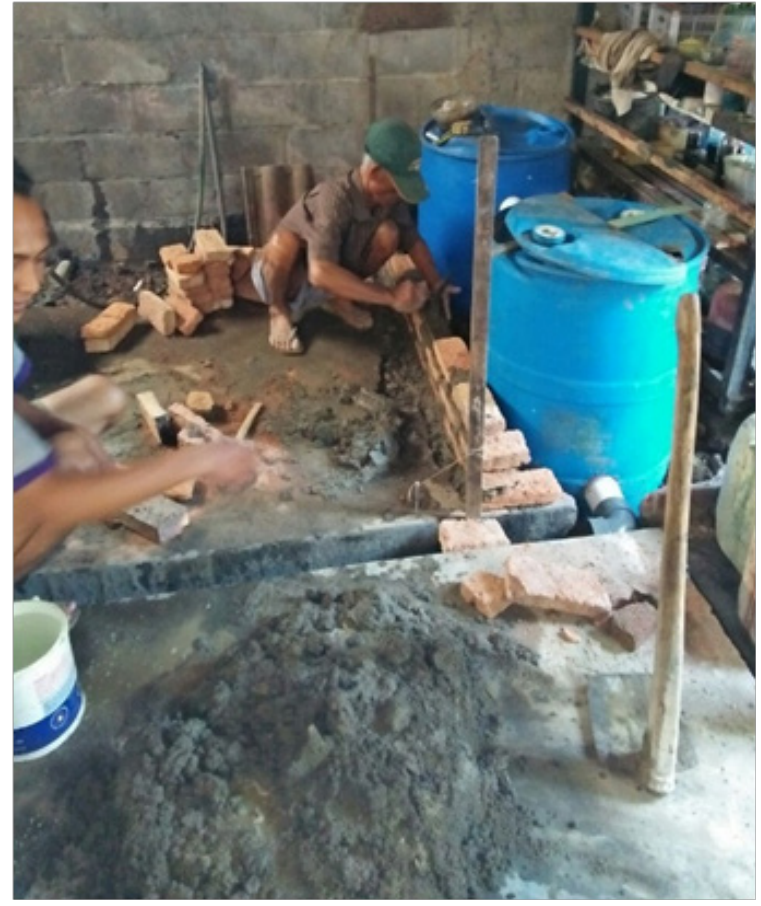

Gambar 4. Pemasangan bata untuk dinding bak tampungan dan pembuatan saluran pembuangan

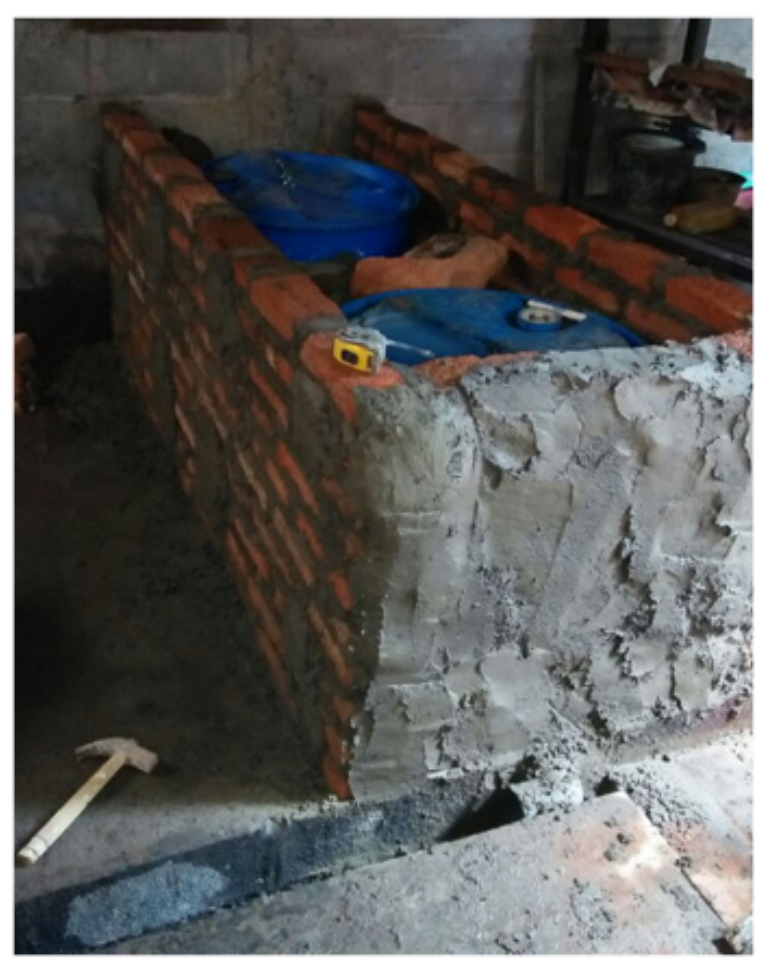

Gambar 5. Pembuatan bak penampung limbah dalam tahap finishing 


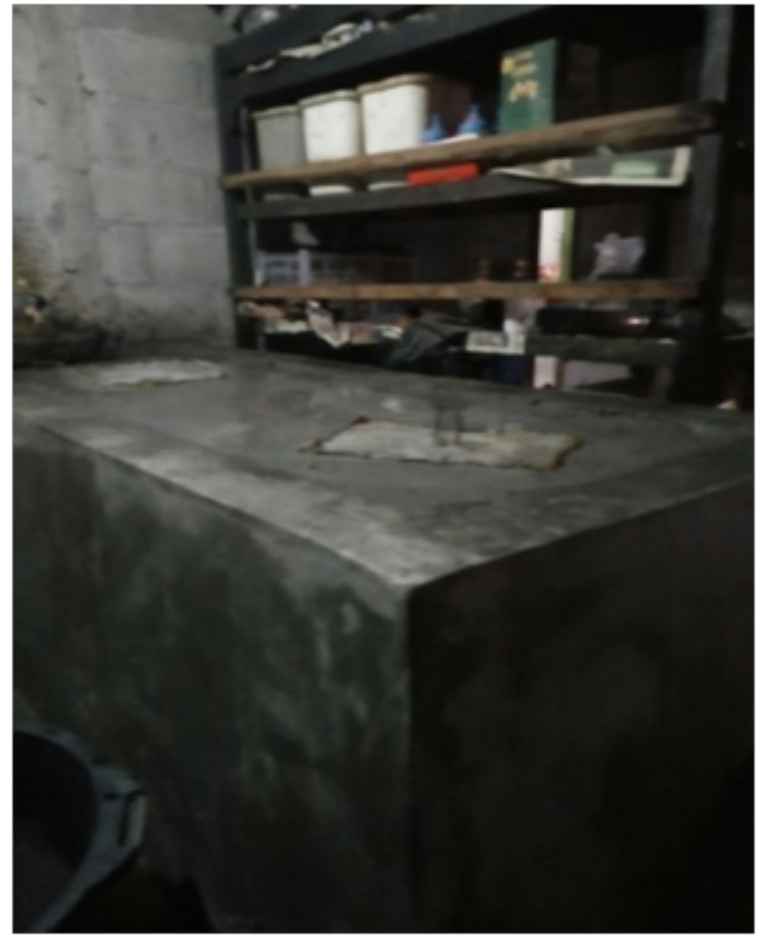

Gambar 5. Pembuatan bak penampung limbah telah selesai

Setelah limbah bak-bak pengolah limbah dibuat, selanjutnya limbah akhir dialirkan ke saluran pembuangan akhir dan dibuang ke lingkungan. Limbah yang dibuang dengan melalui proses pengolahan secara biologis tersebut diharapkan tidak lagi mencemari lingkungan sebagaimana apabila dibuang secara langsung.

\section{KESIMPULAN}

Pemilik maupun pengurus UKM Batik Mutiara Hasta dan Katun Ungu telah menyadari pentingnya pengolahan limbah sebelum dibuang agar tidak membahayakan bagi lingkungan. Melalui kegiatan pendampingan dan pelatihan pengolahan limbah batik yang dilakukan oleh tim pengabdian masyarakat dari Universitas Diponegoro ini proses pengolahan limbah batik dari UKM Mutiara Hasta dan UKM Katun Ungu dapat diperbaiki melalui pengolahan secara biologis dengan menggunakan media batu zeolit, bioball, kerakal dan kerikil. Dengan adanya kegiatan pengabdian ini limbah batik yang dibuang lebih ramah lingkungan dan tidak lagi menjadi sumber pencemar.

Bak pengolah limbah yang telah dibuat sebaiknya selalu dikontrol apakah media yang digunakan sudah mengalami kejenuhan. Apabila sudah jenuh maka proses penjernihan limbah menjadi kurang maksimal sehingga perlu diganti dengan media yang baru. Pengisian bak juga diatur sehingga limbah yang dihasilkan dapat diendapkan lebih dahulu di bak equalisasi sebelum masuk ke bak pengolah.

\section{UCAPAN TERIMA KASIH}

Pada kesempatan ini penulis mengucapkan terima kasih kepada Direktorat Riset dan Pengabdian Masyarakat Kementerian Riset, Teknologi dan Pendidikan Tinggi yang telah mendanai kegiatan pengabdian kepada masyarakat ini melalui program Ipteks bagi Program Unggulan Daerah (IbPUD).

\section{DAFTAR PUSTAKA}

Kementerian Lingkungan Hidup Republik Indonesia, 2014, Baku Mutu Air Limbah, diakses tanggal 28 Agustus 2017

Lestari, N.D. dan Agung, T., Penurunan TSS dan Warna Limbah Industri Batik Secara Elektro Koagulasi, Jurnal Ilmiah Teknik Lingkungan, Vol 6 No 1

Murniati, T. dan Muljadi, 2013, Pengolahan Limbah Batik Cetak dengan Menggunakan Metode Filtrasi-Elektrolisis untuk Menentukan Efisiensi Penurunan Parameter COD, BOD, dan Logam Berat (Cr) Setelah Perlakuan Fisika-Kimia, Ekuilibrium, Vol. 12 No. 1, hal. 27-36 
p ISSN: 1410-9344, e ISSN: 2549-5631

Riyanto, Sidik, N. Y. dan Hidayah, L., 2017, Treatment of Batik Waste Using Distillation Method, AIP Conference Proceedings 1911, 020029, https://doi.org/10.1063/1.5016022

Slamet, R., 2015, Company Profil Mutiara Hasta Batik Courses Classical \& Contemporary, dokumen tidak dipublikasikan

Tangahu, B. V. dan Ningsih, D. A., 2016, Uji Penurunan Kandungan COD, BOD pada Limbah Cair Pewarnaan Batik Menggunakan Scirpus Grossus dan Iris Pseudacorus dengan Sistem Pemaparan Intermittent, Jurnal Sains dan Teknologi Lingkungan, Volume 8, Nomor 2, Juni 2016 Hal. 121-130 